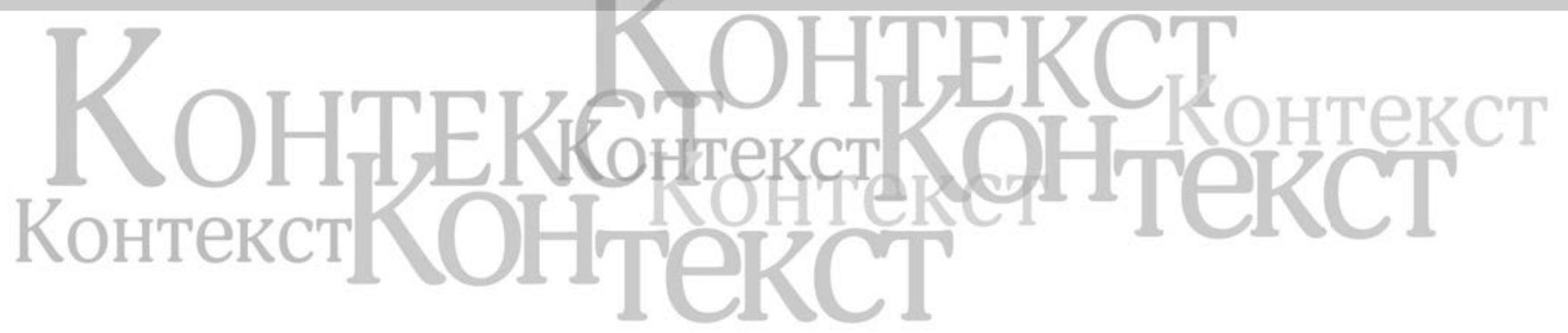

\title{
KOHTEKCT
}

УДК 78.01

ББК $85.310,0$

DOI 10.25281/2072-3156-2020-17-1-4-15

\section{Л.М. ГРИБАНОВА}

\section{МУЗЫКА КАК СИНЕРГИЯ И НЕКЛАССИЧЕСКАЯ МОДЕЛЬ ЧЕЛОВЕКА}

\author{
Людмила Михайловна Грибанова, \\ Международный славянский институт, \\ вокальный фракультет, \\ профессор \\ Годовикова ул., д. 9, стр. 25, Москва, 129085, Россия \\ кандидат педагогических наук \\ ORCID 0000-0003-2605-7649; SPIN 7143-5879 \\ E-mail: snovamila@gmail.com
}

Реферат. $B$ статье рассматривается феномен музыки с точки зрения Человека. Связь с человеком в философии музыки оказывается весьма актуальной и пришедшей на смену позитивизму, а также спекулятизму, свойственным теориям о музыке в прошлом, когда использовались формально-логические методы.

Во внимании оказывается связь между личностным опытом человека, его антропологической энергией, т. е. той, которая связана с сокровенными основами и предельными глубинными переживаниями личности (ужасом, болью, счастьем, восторгом, устремлением за предель себя) и специфической музыкальной энергией. В этом рассмотрении мы опираемся на философскую концепцию современного выдающегося отечественного мыслителя С.С. Хоружего. В ней человек предстает как энергийное существо, формируемое предельным опытом, m. е. опытом достижения предела существования и сознания. Синергийный подход к человеку продолжает неклассическую философскую традицию описания человека, используя категории «энергия», «практика себя», «предельный опыт», «конституциия человека» и исключая категории «сущиность», «субстанция», «субъект», свойственные классическому видению человека в европейской философии XVII-XIX веков.

Антропологическая составляющая неклассической синергийной концепции музыки включает понимание человека через определенную типизацию устремлений к гранище, пределу. Такая философская антропология рисует человека, размыкающегося к нескольким границам - онтологической, онтической и виртуальной.

Музыка, соответственно, представленная как синергия, выступает проявлением человека, оказываясь музыкой онтологического, онтического или виртуального устремления. С этой точки зрения формируется не только особая философская концепция музыки, отличная от 
иных концепций - а именно от концепций музыки как числа и как выражения, но и подход ко всему историческому музыкальному наследию, а также к музыкальной практике, включающей композиторскую, исполнительскую, слушательскую деятельность.

Ключевые слова: философия музыки, музыка как синергия, неклассическая модель человека, антропологическая энергия, предельный опыт, музыка онтологического, онтического и виртуального устремления.

Для цитирования: Грибанова Л.М. Музыка как синергия и неклассическая модель человека // Обсерватория культуры. 2020. Т. 17, № 1. C. 4-15. DOI: 10.25281/2072-3156-202017-1-4-15.

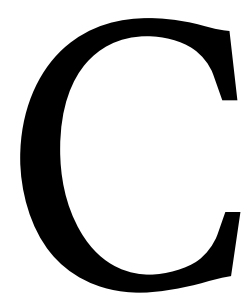

овременная философская концепция музыки, на наш взгляд, должна быть представлена в контексте антропологии. Необходимость и актуальность рассмотрения феномена музыки через антропологию обусловлены всей ситуацией последнего и настоящего времени, связанной с антропологическим кризисом. Мировые войны, террор XX в., экологическое положение, новая биоэтика XXI в. бросают вызов современному человеку, его фундаментальным ценностям, его образу, провоцируют иное, чем прежде, описание человека и строение его модели. Вопрос понимания человека оказывается ключевым и для понимания искусства, в том числе и музыкального. Впрочем, на протяжении всей истории искусства и истории мысли об искусстве наблюдается зависимость их от модели человека, принятой в ту или иную эпоху.

Так, представление о музыке как Числе, свойственное Античной и Средневековой мысли, опирается на модель человека, настроенного на связь с высшей инстанцией. Пифагорейцами было осознано единство математических законов, царящих как в музыке, так и во всей вселенной. Музыка, будучи числом, отражала, являла и одновременно символизировала «гармонию сфер». В христианстве «гармония сфер» осознавалась как сфера ангелов. Во времена от- крытия университетов музыка входила в квадривиум наряду с астрономией, арифметикой и геометрией как наука чисел, связанных с божественным миром. Аниций Манлий Торкват Северин Боэций - римский математик, физик и философ, иерархически распределяя музыку по видам, первую и главную называл «мировой музыкой» - Musica mundana - именно ту, которая отражает «гармонию сфер» (ниже стоит человеческая - humana - и инструментальная - instrumentalis - музыка, соответствующие уровням души и тела) [1, с. 159-161].

Напротив, в представлении о музыке как об искусстве эмоционального выражения претворилась классическая модель человека. Европейская классическая философия рисует человека как носителя некоего центрального ядра сущности, субстанции, эссенции. Данная идея оказалась центральной в философской антропологии Нового времени, в котором подход к человеку включал использование также термина, ставшего аккумулирующим началом в его развитии - человек был определен как субъект. В классическом дискурсе феномен музыки, так же как и модель человека, был наделен неизменным качеством - сущностью, чем является содержание музыки, которое призвано выразиться языковыми средствами. В эстетике же, рожденной в недрах классического сознания, музыка предстала в качестве объекта познания человеком-субъектом.

Классическая модель человека и классический подход к явлению музыки были чрезвычайно проработанными, системными, плодотворными, работоспособными (в музыкальной педагогике до сих пор продолжает быть устойчивой дихотомия содержание-выразительные средства). Между тем, кризис классической модели обнаруживается уже более ста лет назад как в философии, так и в самой практике искусства. На протяжении этих лет было выработано несколько неклассических философских течений (экзистенциализм, феноменология, герменевтика, неомарксистская философия Франкфуртской школы, среди представителей которых вспомним философию Т. Адорно - апологета музыкального авангарда [2]). Но единого подхода и цельной философии, по работоспособности равной классической, нет. Однако назрела потребность в современ- 
ной концепции музыки, построенной на базе неклассической философской антропологии.

Таким актуальным, разработанным и длительным направлением, претендующим на цельность и системность, тяготеющим к снятию противопоставления объекта и субъекта, является феноменология музыки. Однако даже в этом направлении не происходит действительного объединения человека и музыки. В его различных течениях (всего, как отмечает исследователь Р.А. Куренкова, было три волны феноменологии [3]) утверждается либо объективность, либо субъективность музыки. В доказательство первого назовем В. Дильтея, который в рамках первой волны, в 1920-1930-х гг. возвышает музыку над человеком, называя ее тоталитарно-теологическим единством [4], или А. Пайка - философа третьей волны, который в 1980-1990-х гг. сводит музыку к акустическому процессу и не включает в него внемузыкальную, в том числе и человеческую реальность [5]. В качестве примеров акцента на субъекте вспомним феноменологию второй волны, в 1950-1960-х гг., а именно, Р. Ингардена, хоть и обеспокоенного проецированием своих чувств на музыку, все же приветствующего идеальное рефлексивное созерцание музыки вне ее материальной данности [6], а также С. Лангер, которая хоть и следует позиции антипсихологизма, считает музыку выражением эмоциональной жизни человека, имперсональных жизненных процессов чувств, инстинкта, воли [7].

Несмотря на отдельные феноменологические исследования второй и третьей волны, замечающие в музыке «проникновение» в слушателя, его «поглощение» музыкой (Н. Гартман [8]) и «самозабвение» в ней (L. Ferrara [9]), все же чаемое единство музыки и человека оказывается лишь декларативным. Таковое единство должно быть обеспечено чем-то общим как для человека, так и для музыки. Это общее начало замечает иная философия, а именно синергийная антропология С.С. Хоружего $[10 ; 11]$. С его точки зрения энергия является свойственной как музыкальной, так и антропологической реальности. На данном основании строится концепция музыки как синергии, т. е. явлении совместности нескольких энергий.

Сформулируем основные теоретические положения концепции музыки как синергии.
Таковые складываются на основе трактовки трех явлений: человека, музыкальной материи и принципа их взаимодействия.

\section{ЧЕЛОВЕК}

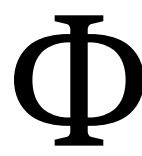
ундамент человека составляет не сущность, а конституция (сформированность) себя в опыте, практике при размыкании себя Другому - характерное положение для неклассической философии в целом. Модель человека в рамках синергийной философской антропологии дорисовывается благодаря вниманию к устремлению человека к антропологической границе (термин «граница» обозначает предел или горизонт существования человека), которое, по С.С. Хоружему, имеет энергийную природу. Энергия устремления к границе именуется антропологической энергией, а ее контакт с энергией по ту сторону границы, т. е. явление совместной энергии называется, по С.С. Хоружему, синергией. Теоретическое положение о человеке сформулируем так: человек как энергийное существо, умеющее жить в нескольких областях устремления к границе, способно к стратегии жизни в каждой отдельной из них или в их смешении. Он непосредственно проявляет это устремление и стратегию в творчестве, в искусстве, в частности, в музыкальном. Границ, согласно синергийной антропологии, всего три онтологическая, онтическая и виртуальная.

Онтологическая граница есть граница, отделяющая человеческую жизнь и Инобытие. Она исходит из изначального корневого отношения человека к собственной смерти. К таковой границе устремлены разнообразные духовные практики. В их синергии участвуют энергия человека и энергия, как отмечает С.С. Хоружий, используя философскую лексику, Внеположного Истока [11, с. 39]. В религиозном дискурсе это значит, что в духовных практиках происходит размыкание человека к Богу (в авраамических религиях), к Дао (в китайском даоизме), к Ничто, нирване (в буддизме), к Космосу, богам (в религии Древних греков, в индуизме).

Онтическая граница располагается в эмпирическом мире. Она отделяет сознание и бессознательные предельные проявления. К ним 
относятся различные комплексы, неврозы, психозы, мании, фобии - так называемые паттерны бессознательного, составляющие предмет психоанализа. На этой границе и в тяготении к ней (в топике) происходит обмен энергии человека (его сознательных проявлений - воли, целеустремления и т. п.) и энергии бессознательного, которая питает разомкнутого к нему человека.

Третий вид границы отделяет эмпирическую реальность от виртуальной. Выходы в виртуальный мир также оказываются предельными проявлениями размыкающегося к нему человека. Это и виртуальные игры, и общение в Сети, и массмедийное сознание, и измененное состояние под воздействием психоделических средств. Симулякры представляют собой сформированные сущности виртуальной границы. Человек в устремлении к ней входит в «как бы реальность», испытывая предельный опыт (например, вне физических законов действия героев компьютерной игры или возможность осуществлять глобальные процессы - вести военные действия, запускать спутник - способны захватить человека до ухода в эту, как ему кажется, подлинную и альтернативную обыденности реальность). Входя в виртуальные практики, человек открывает альтернативу эмпирическому миру, полную яркой надуманности. В этой искусственности кроется источник энергии, связанной с ожиданиями иной свободной реальности.

\section{МУЗЫКА}

卫 Ірактовка музыкальной материи, из которой соткано музыкальное искусство, должна преодолеть привычную для любого музыканта дихотомию содержания и выразительных средств. Альтернативным ей является энергийный подход к музыке. В отечественном музыкознании еще до войны наиболее значительно его претворил Б.В. Асафьев, который с энергийной точки зрения исследовал интонационный процесс [12]. Хотя близкие идеи к ней уже звучали в ту же пору и оказывали влияние на музыковеда, а именно теория звукового тяготения Б.Л. Яворского (сам Б.В. Асафьев признавал себя его учеником [13]) и учение А.Ф. Лосева о музыке как становлении (параллели в трудах двух крупнейших ученых показал Г.Р. Консон [14]). Надо сказать, что необычный и по советскому времени даже крамольный взгляд на музыку как на энергию испытал сопротивление и официальное осуждение.

Хотя широкий характер смысла интонации чувствовал не только Б.В. Асафьев. Открытие его принадлежит русскому музыкознанию, но цельную интонационную концепцию сделал именно Б.В. Асафьев. Он впервые разрабатывал это понятие в координации с жизнью человека, впервые оно не разлагалось на языковые элементы (ритм, высота и т. д.), но выступало цельным явлением - как смысловое звуковыявление.

В асафьевском термине «интонация» сошлись и синтезировались два совершенно разных варианта его употребления. Во-первых, имеется в виду значение как мелодического движения (интонация проявляется в сочетании звуков как отношений); во-вторых - значение, связанное с понятием «энергия» (по Б.В. Асафьеву, даже один тон может иметь напряжение и стимул движения). Много переплелось в асафьевском термине «интонация»: и смысл, и мелодическое движение, и энергия, тождественная тону, тонусу, тоновому напряжению. Все же главным понятием из них является «энергия», которое ученый ставит во главу угла своей интонационной теории.

Слово «энергия» употребляется музыковедом в смысле «музыкальная энергия». Б.В. Асафьев пишет: «Понятие энергии предполагает за собой понятие музыкального движения и сил или стимулов, его вызывающих и в нем действующих» [12, с. 55]. Интонация и есть энергия.

Основная проблема первой части книги Б.В. Асафьева «Музыкальная форма как процесс» есть проблема движения. Введение понятия «интонация» в теоретическую разработку феномена музыки наложило печать на исследование ее временной природы. В контексте интонационного учения источником временного музыкального движения признается тоже энергия. Он исследует энергийные стимулы, обусловливающие интонационное развитие. Ученый их называет кинетической энергией. Таковая, по Б.В. Асафьеву, порождается стол- 
кновением стимулов равновесия (консонанс, терцовые тональные соотношения) и «взрывчатых сил» (вводный тон, мнимый каданс, задержания, диссонанс, автентизм). Б.В. Асафьев трактует музыкальное движение как «состояние неустойчивого равновесия, замкнутое между первым толчком и замыкающим движением, конечной формулой как точкой восстановленного равновесия» [12, с. 59].

Как известно, на учение Б.В. Асафьева повлияла также энергетическая концепция выдающегося швейцарского музыковеда и философа Э. Курта. В своей книге «Основы линеарного контрапункта» [15] Э. Курт объясняет композиторскую технику И.С. Баха как результат энергетического «волнового движения» отдельных линий. Музыковед постоянно оперирует понятиями «сила» и «энергия». Ученый показал, что закономерность и логика развития одноголосной мелодической линии определяется энергийной горизонтальной динамикой развертывания, т. е. свободным широким дыханием мелодии, не подчиняющимся действию вертикальных расчленяющих гармонических и метроритмических факторов. Ярче всего эта закономерность проявилась по Э. Курту в стиле И.С. Баха. По отношению к ней ученый применяет понятие «кинетическая энергия», которое позже уже использовал и Б.В. Асафьев. Э. Курт заимствует из физики также понятие «потенциальной энергии» в определении гармонии, так как по Э. Курту она обусловливается тяготениями тонов и их стремлением к движению [16, с. 41-42].

Второе теоретическое положение синергийной концепции музыки применительно к музыкальному материалу таково: звучащее вещество есть энергийный процесс, соотношение стимулдвижение, импульс-поток, сочетание кинетической и потенциальной энергии, интонация, представляющая собой одновременно это сочетание и звукоявленный смысл.

\section{ЧЕЛОВЕК И МУЗЫКА}

B осмыслении взаимодействия человека и музыки в рамках неклассической ее концепции должны отрезонировать теории человека как энергийного существа и музыки как энергии. Однако сначала посмотрим на решение проблемы соотношения человек музыка (музыкальный материал) в иных концепциях музыки.

Б.В. Асафьев, опираясь на понятие энергии, употребляет его, помимо приведенного выше смысла, еще в другом значении, связанном с немузыкальной сферой. Композитор борется с пониманием музыки как «натуралистического раскрытия чувственной сферы». Он пишет, что «чувственный, то есть эмоциональный тонус, неизбежно присущий музыке, не является ее причиной, ибо музыка - искусство интонируемого смысла. Оно обусловлено природой и процессом интонирования человека» $[12$, с. $343-344]$. Ученый в качестве причины говорит о разумной деятельности человека, о его сознании. Жизненная энергия композитора преображается, переводится с помощью мозга и интеллекта в энергию звуков. Музыкальное движение, по Б.В. Асафьеву и в соответствии с концепцией музыки как выражения, есть «управляемое эмоционально-смысловое воздействие», «становление психической деятельности в звучании» [12, с. 344-345]. Это становление осуществляется на уровне личности и на уровне социума: жизненная энергия социума и «общественная значимость интонации» - народа, социальной группы, какой-либо общности (деревни, например) - формирует так называемый интонационный словарь, отобранный как наиболее привычный, устоявшийся и доходчивый комплекс интонаций, связанный с конкретным местом и временем проживания людей, особенностью среды, темпа жизни, исторических обстоятельств и т. д. Так, в специфических формах музыкальных интонаций происходит «выявление общественного сознания» [12, с. 355]. Добавим здесь, что Э. Курт видел причину музыкальной энергии в психике, в «душевной воле, духовных ориентирах, в мироощущении эпохи» $[15$, с. 9].

Интонирование и человеческая внемузыкальная сфера внутри концепции музыки как выражения сопоставляются в мыслительном режиме параллелизма, горизонтальности, выявления, выражения. Одно учитывается на эмпирическом реальном уровне, другое - на идеальном концептуальном. Иначе рассматривается соотношение человек - музыкальный материал в концепции музыки как числа. 
Согласно этой концепции реальное звучащее музыкальное время трактуется как овеществление числа, его становление. А.Ф. Лосев - создатель философской теории музыки, которую выдающийся музыковед Ю.Н. Холопов назвал лучшей в XX в., - убеждает, что подлинный феномен музыки внепространственен ${ }^{1}$, что он не имеет ни тяжести, ни веса, что смысл музыки «никогда и ни при каких обстоятельствах не может быть отличен признаками физическими, физиологическими или психологическими» $[17$, c. 41], что он есть число, абсолютная пустота, «слышимое ничто» [17, с. 47]. Человек, духовно настроенный, призван проникнуть в надмирную стихию, в небесную ангельскую «прослойку бытия», чтобы расслышать ее музыку и отразить в музыкальном веществе. Активность участия человека в этом процессе мыслится, главным образом, в аспекте восприятия, слу$x a$, подражания и отражения, воплощения, т. е. в режиме не параллельности, а от «лица» числа, в режиме вертикального нисходящего вектора.

В синергийной концепции музыки отношение человек - музыка описывается по-другому. Обратимся к замечательному русскому музыковеду В.В. Медушевскому, позиция которого, на наш взгляд, является пограничной между ней и предыдущей концепцией.

Ученый прибегает к понятиям энергии, интонации, соответствующим синергийному подходу. В интонации он видит «скрепленное энергиями смысла нерасторжимое единство всех сторон звучания» [18, с. 33]. В музыкальном искусстве он находит претворение энергии в некоторый смысл, который не есть «мертвая познавательная структура», а «живая личностная реальность» [18, с. 48].

В интонации В.В. Медушевский выделяет протоинтонацию и аналитический стержень оформившейся интонации. В первой присутствует сгусток духовной энергии. Именно здесь, по мнению ученого, происходит встреча человека и божественных энергий.

Такая трактовка зарождения интонации, выдающая синергийный взгляд на музыку, по-

1 Г.Р. Консон пишет, что лосевская идея эйдоса в музыке (понимаемого, в числе прочего, как смысл, связанный с логосом) передалась Б.В. Асафьеву, что, однако, после войны музыковед признавал в интонации не только смысл, но также чувство и волю [14, с. 23]. зволяет его обладателю за каждым языковым явлением разглядеть устремление человека к онтологической границе. Примеров духовного анализа, как выражается сам В.В. Медушевский, в его последней книге очень много. Вот несколько из них: разрешение диссонанса в консонанс музыковед-философ интерпретирует как религиозное понятие, показывающее «непрерывную тренировку» и «легкую радость от сброшенной горы грехов»; трезвучие он мыслит как абсолютное единство и абсолютную раскрытость тонов друг в друге, «выражающую истину христианского откровения о Боге и человеке» [18, с. 72].

Ученый разносторонне, чрезвычайно многочисленно фактически проиллюстрировал возможность синергийного анализа музыки. Он усматривает богообщение даже в, казалось бы, не очевидной для этого музыке: например, финал 5-й симфонии Людвига ван Бетховена В.В. Медушевский интерпретирует как «радость славы Божией, образ небесного спасения в нескончаемой ревности к свету»; или государственный гимн А. Александрова - как продолжение традиции русского молитвенного, исполненного могучей и полной любви к Богу, славословия. Он верит в генеральную цель серьезной музыки. «Вектор возвышения души к Богу есть скрытый все пронизывающий молитвенный стержень великой музыки», - пишет музыковед [18, с. 527].

В.В. Медушевский принимает и законный противовес этому стержню - присутствие в данной музыке мирского, земного начала. Однако полностью исключает из ее «семьи» ту музыку, у которой нет и не может быть богообщения, в которой царят «энергии самости» и «дьявольские качества» $[18$, с. 40]. Он классифицирует всю музыку на хорошую (священную, ангелоподобную) и плохую (в лучшем случае, человеческую, в худшем - сатанинскую), на стиль и антистиль (например, авангардизм видится ученому «вирусной программой, изготовленной адом» [18, с. 287]. Всякая музыка, по В.В. Медушевскому, неизбежно соотнесена с божественным, положительным образцом - либо отрицательным (например, в рок-музыке).

Однако здесь необходимо признать уязвимость позиции ученого. Несомненно, правило распределения в музыке знаков «+» и «-» не 
имеет универсального значения. Усмотрение наверняка в какой-либо музыке действия божественных энергий или его отсутствия возможно на уровне личного бездоказательного суждения, оценочной позиции, определенного рода художественного высказывания. Трактовка тех начал и энергий, которые действуют с другой, чем человек, стороны на основе только творческого продукта, без оглядки на человека, может быть ошибочной. Например, для христиан анализ академической музыки В.В. Медушевским может быть близок, но для буддиста, скажем, он покажется обманом, иллюзией, или для психоаналитика - игрой с собственным подсознанием, для атеиста - фантазией. Рок-музыкант (как и адепт рок-музыки), конечно, никогда не согласится с тем, что он создает сатанинскую мелодию.

Во избежание такого «перекоса» или «методологической ошибки», как выразился К.В. Зенкин [19, с. 403], но оставаясь на позициях синергийной антропологии, необходимо следовать мыслительному режиму не нисходящего вектора, т. е. от лица свыше, но восходяще20 вектора, т. е. от лица человека, его устремлений к границам, связанным с личным выбором.

В рамках синергийной концепции музыки ${ }^{2}$ лишь предполагается, имеется в виду действие энергии запредельного начала по ту сторону границы, к которой устремлен человек. Энергию движения человека к границе, т. е. энергию антропологической реальности, согласно этой концепции, следует описывать с помощью таких слов, как устремление, восхождение. У нас имеется в виду не конкретно возвышение человека по духовной лестнице (данное значение, как известно, применимо только к онтологической топике, к дискурсу определенных духовных практик), но импульс, исходящий изнутри человека вовне, желание оказаться над повседневностью - даже если движение происходит, например, вглубь психики и сознания.

Отношение «человек - музыка» в свете сказанного раскроем как отношение антропологической энергии и энергии музыкального

2 Проблемы синергетики музыки разрабатывает также А.С. Клюев, однако совсем в ином ключе: музыку ученый понимает как систему и продукт эволюции движения материи. Синергию в его подходе можно усмотреть в механизме интеграции уровней эволюции материи [20]. материала. И первое, и второе есть проявление человека. Согласно нашей концепции обе энергии находятся во взаимодействии. Импульс человеческого устремления дает толчок звуковой энергии, приводит в движение поток звучания. Осуществляется сцепление энергий, их передача друг другу. Глубинный сокровенный внутренний импульс и импульс протоинтонации взаимодействуют в «сверхзвуковых» условиях - по «сценарию» заражения, вовлечения, проникновения, и потому мыслятся в единстве.

Такая же сцепка предполагается и в обратном пути: от звуковой реальности к реальности антропологического устремления. Музыкальная энергия обладает свойством забирать с собой всего человека (душу, тело) к тем высотам, от которых питалась сама. Звуковая реальность может сообщить, увлечь, восхитить человека.

Приведем пример: на грузинском шоу «Ничиери» девятилетняя девочка Мариам Урушадзе спела песню «Памяти Карузо» (композитор Л. Далла). Зрители шоу в зале дружно вставали с мест, на их лицах читались: восторг, любовь, печаль, какая-то душевная уязвимость... Все это вызвали каких-то 4 такта - а благодаря им просквозил у меня лично и страх смерти, и страдание, и крушение, и тоска, и переживание предела жизни, и невыразимая радость... Конечно, они были подготовлены куплетом: в нем спокойно и одновременно как бы скороговоркой ведется речь о море, ветре, девушке в слезах (гармонически спокойствие, даже, скорее, смиренность поддержано обыкновенным полным функциональным ходом), главный звук куплета - начальный, долгий, тонический, во второй фразе - опять он же. И с него же начинается будто на крыльях воспарение мелодии припева тремя шагами вверх к тому, чтобы ненадолго остаться на печальной, глубокой, сильной III ступени минора и затем устало, с тритоновым изломом, спуститься. Но, взяв дыхание, немного оттолкнувшись от квинтового тона доминанты, мелодия обретает энергию взлета еще выше, чтобы потом снова успокоиться на тонике. Слушая эти 4 такта, невозможно было не заплакать вместе с залом. Будто вот здесь сейчас происходит миг, исполненный красоты, правды, последней острой значимости. В нем концентрированно воплотилось то, 
что словами сказано в третьем куплете: «Гляжу я в море и вижу жизнь прошедшую свою, Как белый след ушедших в гавань кораблей... Возможно дни мои к концу подходят, верно, Но думать стоит ли, жалеть о том, я счастлив»... В дальнейшем в песне есть снова и снова переживание этого мига.

Но что может знать маленькая девочка обо всем этом? Глядя в ее детское чистое лицо и слушая ее прекрасный крепкий голос, точно знаешь, что здесь не может быть фальши, и веришь, словно ангелу - безоглядно, безостановочно, предельно.

В этом беглом наброске энергийного анализа одной фразы мелодии песни, конечно, присутствует фиксация и выразительных средств (III ступень минора, тритон, доминантовый квинтовый тон, восходящее движение), и содержания (печаль прошедшей жизни). Разница с обычным, скажем, школьным анализом заключается в установке на изначальное энергийное единство, в данном случае, песни и воспринимающего человека (конкретно, автора этих строк) - его жизни, экзистенциального чувства, во впускании этого произведения в себя, ощущение его частью собственной жизни.

В приведенных словах о музыке этой песни есть попытка передать слушательское вовлечение в музыкальную энергию и одновременно в антропологическую энергию предельного опыта и нацеленности на восторг, биение, концентрацию жизни - на ужас и счастье.

\section{ПРАКТИКА СЕБЯ}

Б лагодаря единству музыкальной и антропологической энергии музыка предстает как коммуникативное явление. Импульс, сгусток энергии - антропологический и музыкальный - способен передаваться каждому из участников музыкального общения. Такая трансляция возможна в опыте совместной творческой деятельности. Им - этим опытом - характеризуются, например, лучшие уроки музыки, когда между педагогом и учащимся образуется несказанная связь.

С точки зрения синергийной концепции, не в схоластическом спекулятивном мышлении, оперирующем отвлеченными вещами, сущностями, но находясь внутри музыкального общения, проявляясь не только мыслительно, но и телесно, энергийно, человек призван испытать опыт, осуществить практику, в результате чего возможны внутренние изменения. Стабильно и терапевтически они вряд ли могут «сотрясти» глубинные антропологические основания, т. е. отношения человека с границей, его идентичность, самоощущение. Все это вырабатывается в особых ситуациях личной жизни каждого человека, в душевных потрясениях. Само по себе общение в музыкальной деятельности и творчестве еще не есть предельный опыт. Но оно, если пережито, повторяется, репетируется, актуализируется, воспроизводится. Если же в жизни человек не испытал ничего поворотного, то это общение способно «разрыхлить» почву внутреннего мира, взбудоражить, сделать более восприимчивым и эмпатийным этого человека. Как пишет С.С. Хоружий, «эстетические практики развивают и прорабатывают идентичность, дают ей достичь полноты реализации; но при этом сам тип и характер идентичности остается, каким он был исходно заложен в отношениях человека с Границей» [11, с. 355].

Таким образом, музыка, понятая как синергия, неизбежно оказывается и коммуникацией, и опытом, и практикой себя. «Практика себя» - важное понятие современной антропологии, вошедшее в широкий обиход благодаря философии М. Фуко [21]. Для него это есть «намеренные и отрефлексированные практики, посредством которых люди не только устанавливают для себя правила поведения, но и стремятся преобразовать самих себя, измениться в своем уникальном бытии, сделать свою жизнь собственным произведением» (цит. по: $[10$, c. 499]). Синергийный подход к музыке обнаруживает в ней вообще, а не только в новой экспериментальной музыке Дж. Кейджа, как цитирует современного философа А.Н. Липов, нечто, что «требует от нас “выполнить ее”... чтобы заманить нас в неизвестные практики» [22, с. 705].

Учитывая типологию антропологических влечений, легко допустить и различные типы музыки - в зависимости от них. История музыки показывает, что доминирующим тяго- 
тением в музыке от древности до ХХ в. было онтологическое устремление. Об этом свидетельствует не только весь мировой фольклор, не только музыкальная традиция христианского мира, от которой берет начало вся последующая европейская академическая музыка (в том числе и русская академическая), но и музыка, связанная с иными религиозными практиками. B XX в. психоанализа выходит на первый план гипнотическая музыка, притупляющая и обходящая контроль разума и сознания. Примерами таковой послужат произведения обеих волн авангарда. XXI в. характеризуется новой доминантой - устремлением к воображаемой границе.

Виртуальная музыка не ориентируется на психологию восприятия, на исполнительские возможности и т. п. условия психофизики человека. Вымышленность образуется за счет построения особого гиперзвукового мира (гиперритмичного, гиперскоростного и т. д.) с помощью электронных устройств. Не просто оригинальность звука, но его немыслимая искусственность стала «доро́гой» в «неведомую пугающую новизну», как об этом пишет историк музыки В. Ерохин [23]. Он отмечает, что уже во 2-й половине XX в. на волне второго авангарда происходило осмысление порога в истории музыки, за которым ее ждало нечто совершенно новое, не связанное с многовековым, единым и устоявшимся музыкальным прошлым. Музыка, будучи синергией, способна быть той практикой по формированию «киберпространства» и «биоэлектронной среды», о которых в научной литературе сегодняшнего дня уже присутствуют культурологические исследования [24].

Наше третье теоретическое положение синергийной концепции музыки заключается в том, что антропологические проявления едины с музыкальным материалом, что таковое единство обеспечивается энергийным началом, что оно - это энергийное начало - исходит снизу - от человека и восходит к той или иной границе, встречаясь с запредельной энергией, что антропологическая энергия устремления к трем границам возбуждает к жизни разную музыку, что музыка, в свою очередь, есть проявление онтологического, онтического или виртуального человека.

\section{Список источников}

1. Боэций А. М. С. Наставление музыки // Музыкальная эстетика западноевропейского Средневековья и Возрождения. Москва : Музыка, 1966. C. $153-167$.

2. Adorno T.W. Aesthetic Theory: (Theory and History of Literature). Minneapolis : University of Minnesota Press, 1998. 376 p.

3. Куренкова Р.А. Этюды к феноменологической эстетике музыки : монография. Владимир : Изд-во ВлГУ, 2015. 200 с.

4. Дильтей В. Наброски и критика исторического разума. Приложение. Понимание музыки // Вопросы философии. 1988. № 4. С. 135-152.

5. Pike A. Foundational Aspects of Musical Perception. A Phenomenological Analysis // Philosophy and Phenomenological Research. 1974. Vol. 34, № 3. P. 429- 434.

6. Ингарден Р. Музыкальное произведение и вопрос его идентичности // Исследования по эстетике. Москва : Иностр. лит., 1962. С. 403-570.

7. Langer S.K. Philosophy in a New Key: A Study in the Symbolism of Reason, Rite and Art. Cambridge : Harvard University Press, 1974. 313 p.

8. Гартман Н. Эстетика : пер. с нем. / под ред. А.С. Васильева. Москва : Изд-во иностр. лит., $1958.692 \mathrm{c}$.

9. Ferrara L. Phenomenology as a Toll for Musical Analysis // The Musical Quarterly. 1984. Vol. LXX, № 3. P. 355-373.

10. Хоружий С.С. Фонарь Диогена. Критическая ретроспектива европейской антропологии. Москва : Институт философии, теологии и истории св. Фомы, 2010. 688 с.

11. Хоружий С.С. Очерки синергийной антропологии. Москва : Институт философии, теологии и истории св. Фомы, 2005. 408 с.

12. Асафьев Б.В. Музыкальная форма как процесс. Кн. 1-2. Ленинград: Музгиз [Ленингр. отд-ние], $1963.378 \mathrm{c}$.

13. Консон Г.Р. Болеслав Леопольдович Яворский [Электронный ресурс] // Проблемы музыкальной науки. 2012. № 1. С. 165170. URL: http://journalpmn.com/index.php/ PMN/article/view/426/419 (дата обращения: 10.08.2019).

14. Консон Г.Р. А. Лосев - Б. Асафьев: смысловые параллели [Электронный ресурс] // Проблемы музыкальной науки. 2010. № 1 (6). С. $21-$ 25. URL: http://journalpmn.com/index.php/ 
PMN/article/viewFile/592/591 (дата обращения: 10.08.2019).

15. Курт Э. Основы линеарного контрапункта : Мелодическая полифония Баха / пер. 3. Эвальд. Москва : Музгиз, 1931. 304 с.

16. Курт Э. Романтическая гармония и ее кризис в «Тристане» Вагнера. Москва : Музыка, 1975. $552 \mathrm{c}$.

17. Лосев А.Ф. Музыка как предмет логики. Москва : Академический проект, 2012. 205 с.

18. Медушевский В.В. Духовный анализ музыки : [в 2 ч.]. Москва : Композитор, 2014. 630 с.

19. Зенкин К.В. Музыка. Эйдос. Время. А.Ф. Лосев и горизонты современной науки о музыке. Москва : Памятники исторической мысли, 2015. $462 \mathrm{c}$.

20. Клюев А.С. Что такое музыка с точки зрения синергетики [Электронный ресурс] // Общество. Среда. Развитие. (Terra Humana). 2010. С. 125129. URL: https://cyberleninka.ru/article/v/chto- takoe-muzyka-s-tochki-zreniya-sinergetiki (дата обращения: 11.08.2019).

21. Фуко М. Герменевтика субъекта / пер. с фр. А.Г. Погоняйло. Санкт-Петербург : Наука, 2007. $677 \mathrm{c}$.

22. Липов А.Н. Экспериментальная музыка композитора Джона Кейджа и проблемы американского музыкального авангарда XX века // Обсерватория культуры. 2017. Т. 14. № 6. С. 702-709. DOI: 10.25281/2072-3156-2017-14-6-702-709.

23. Ерохин В. Фономонтаж, прагматроника, логография. Историко-теоретические заметки о некоторых нетрадиционных формах музыкального творчества // Музыкальная академия. 1997. № 2. C. 123-133.

24. Кириллова Н.Б. «Виртуальная реальность» и «виртуализация культуры» как концепты современной культурологии // Обсерватория культуры. 2017. T. 14. № 5. С. 524 -531. DOI: 10.25281/2072-3156-2017-14-5-524-531.

\section{Music as Synergy and Non-Classical Model of Man}

\section{Lyudmila M. Gribanova}

International Slavic Institute, 9, Building 25, Godovikova Str., Moscow, 129085, Russia ORCID 0000-0003-2605-7649; SPIN 7143-5879 E-mail: snovamila@gmail.com

\begin{abstract}
The article explores the phenomenon of music from the viewpoint of Man. In the philosophy of music, the connection with man is getting relevant, replacing the positivism, as well as the speculatism, common to music theories in the past, when formal logical methods were used.

The article focuses on the connection between man's personal experience, his or her anthropological energy, that is the one that comes from the innermost foundations and utmost underlying feelings of the person (horror, pain, happiness, delight, and self-transcendence), and specific musical energy. In this rendering, we rest on the philosophical concept of the outstanding modern Russian thinker Sergey Khoruzhy. He describes man as an energetic entity formed by a limit-experience, which is the experience of reach-
\end{abstract}

ing the limits of existence and consciousness. The synergistic approach to man continues the non-classical philosophical tradition of building the model of man using the categories like "energy", "self-practice", "limit-experience", "constitution of man" and excluding the categories like "entity", "substance", "subject" present in the classical vision of man in European philosophy of the 17th-19th centuries.

The anthropological component of the non-classical synergistic concept of music includes the comprehension of man through a certain typification of man's striving to reach the limits. This philosophical anthropology depicts man opening up to the ontological, ontical and virtual limits.

Music, as such synergy, stands for a projection of man, thus becoming the music of ontological, ontical and virtual striving. From this point of view, not only a specific concept of music is formed, different from other concepts, such as the concepts of music as a number and as an expression, but also an approach to the entire historical musical legacy and to musical practice, including composer's, performer's and listener's activities.

Key words: philosophy of music, music as synergy, non-classical model of man, anthropological 
energy, limit-experience, music of ontological, ontical and virtual striving.

Citation: Gribanova L.M. Music as Synergy and Non-Classical Model of Man, Observatory of Culture, 2020, vol. 17, no. 1, pp. 4-15. DOI: 10.25281/2072-3156-2020-17-1-4-15.

\section{References}

1. Boëthius A.M.S. The Instruction to Music, Muzykal'naya estetika zapadnoevropeiskogo Srednevekov'ya i Vozrozhdeniya [Musical Aesthetics of the Western European Middle Ages and Renaissance]. Moscow, Muzyka Publ., 1966, pp. 153- 167 (in Russ.).

2. Adorno T.W. Aesthetic Theory: (Theory and History of Literature). Minneapolis, University of Minnesota Press Publ., 1998, 376 p.

3. Kurenkova R.A. Etyudy $k$ fenomenologicheskoi estetike muzyki: monografiya [Etudes to the Phenomenological Aesthetics of Music: monograph]. Vladimir, VlGU Publ., 2015, 200 p.

4. Dilthey W. Sketches and Criticism of Historical Reason. Application. Understanding of Music, Voprosy filosofii [Russian Studies in Philosophy], 1988, no. 4, pp. 135- 152 (in Russ.).

5. Pike A. Foundational Aspects of Musical Perception. A Phenomenological Analysis, Philosophy and Phenomenological Research, 1974, vol. 34, no. 3, pp. 429- 434.

6. Ingarden R. The Work of Music and the Problem of Its Identity, Issledovaniya po estetike [Research on Aesthetics]. Moscow, Inostrannoi Literatury Publ., 1962, pp. 403-570. (in Russ.).

7. Langer S.K. Philosophy in a New Key: A Study in the Symbolism of Reason, Rite and Art. Cambridge, Harvard University Press Publ., 1974, 313 p.

8. Hartmann N. Estetika [Aesthetics]. Moscow, Inostrannoi Literatury Publ., 1958, 692 p.

9. Ferrara L. Phenomenology as a Toll for Musical Analysis, The Musical Quarterly, 1984, vol. LXX, no. 3, pp. 355-373.

10. Khoruzhy S.S. Fonar' Diogena. Kriticheskaya retrospektiva evropeiskoi antropologii [Diogenes' Lantern. A Critical Retrospect of European Anthropology]. Moscow, Institut Filosofii, Teologii i Istorii sv. Fomy Publ., 2010, 688 p.

11. Khoruzhy S.S. Ocherki sinergiinoi antropologii [Essays on Synergetic Anthropology]. Moscow, Institut Filosofii, Teologii i Istorii sv. Fomy Publ., 2005, $408 \mathrm{p}$.
12. Asafyev B.V. Muzykal'naya forma kak protsess $[\mathrm{Mu}-$ sical Form as a Process], book 1-2. Leningrad, Muzgiz Publ., 1963, 378 p.

13. Konson G.R. Boleslav Leopoldovich Yavorsky, Problemy muzykal'noi nauki [Music Scholarship], 2012, no. 1, pp. 165-170. Available at: http://journalpmn.com/index.php/PMN/ article/view/426/419 (accessed 10.08.2019) (in Russ.).

14. Konson G.R. A. Losev - B. Asafyev: Parallel Interpretations, Problemy muzykal'noi nauki [Music Scholarship], 2010, no. 1 (6), pp. 21-25. Available at: http://journalpmn.com/index.php/PMN/ article/viewFile/592/591 (accessed 10.08.2019) (in Russ.).

15. Kurth E. Osnovy linearnogo kontrapunkta: Melodicheskaya polifoniya Bakha [Foundations of Linear Counterpoint: Bach's Melodic Polyphony]. Moscow, Muzgiz Publ., 1931, 304 p.

16. Kurth E. Romanticheskaya garmoniya i ee krizis $v$ "Tristane" Vagnera [Romantic Harmony and its Crisis in Wagner's “Tristan”]. Moscow, Muzyka Publ., 1975, $552 \mathrm{p}$.

17. Losev A.F. Muzyka kak predmet logiki [Music as a Subject of Logic]. Moscow, Akademicheskii Proekt Publ., 2012, 205 p.

18. Medushevsky V.V. Dukhovnyi analiz muzyki [Spiritual Analysis of Music]. Moscow, Kompozitor Publ., 2014, $630 \mathrm{p}$.

19. Zenkin K.V. Muzyka. Eidos. Vremya. A.F. Losev i gorizonty sovremennoi nauki o muzyke [Music - Eidos - Time. A.F. Losev and Horizons of the Modern Musicology]. Moscow, Pamyatniki Istoricheskoi Mysli Publ., 2015, 462 p.

20. Klyuev A.S. What Is the Music from the Point of View of Synergetics, Obshchestvo. Sreda. Razvitie. (Terra Humana) [Society. Environment. Development. (Terra Humana)], 2010, pp. 125-129. Available at: https://cyberleninka.ru/article/v/ chto-takoe-muzyka-s-tochki-zreniya-sinergetiki (accessed 11.08.2019).

21. Foucault M. Germenevtika sub"ekta [The Hermeneutics of the Subject]. St. Petersburg, Nauka Publ., 2007, $677 \mathrm{p}$.

22. Lipov A.N. The Composer John Cage's Experimental Music and the Problems of the American Musical Avant-Garde of the 20th Century, Observatoriya kul'tury [Observatory of Culture], 2017, vol. 14, no. 6, pp. 702-709 (in Russ.). DOI: 10.25281/2072-3156-2017-14-6-702-709. 
23. Erokhin V. Phonomontage, Pragmatronics, Logography. Historical and Theoretical Notes on Some Non-Traditional Forms of Musical Art, Muzykal'naya akademiya [Musical Academy], 1997, no. 2, pp. 123-133 (in Russ.).
24. Kirillova N.B. "Virtual Reality" and "Virtualization of Culture" as Concepts of Modern Cultural Studies, Observatoriya kul'tury [Observatory of Culture], 2017, vol. 14, no. 5, pp. $524-531$ (in Russ.). DOI: 10.25281/2072-3156-2017-14-5-524-531.

\section{НОВОЕ ИЗДАНИЕ}

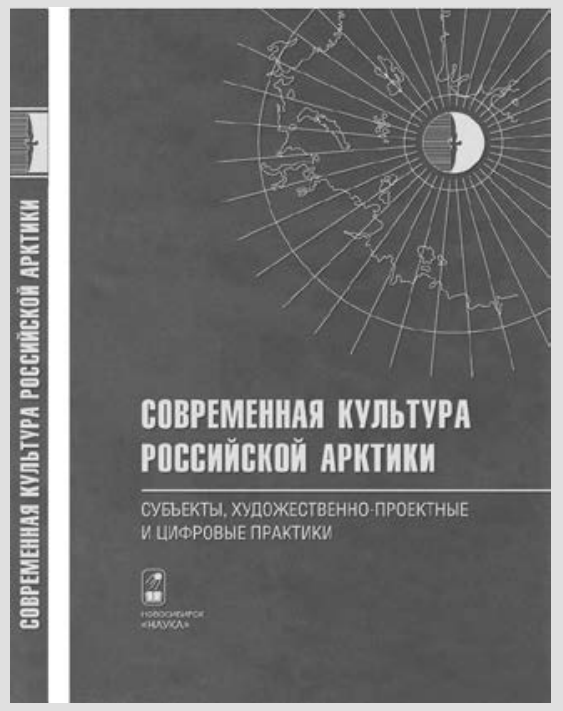

Современная культура Российской Арктики: субъекты, художественно-проектные и цифровые практики : коллективная монография / Арктический гос. институт культуры и искусств; науч. ред. доктор культурологии, профессор О.В. Шлыкова. Новосибирск : Наука, 2019. 216 с.

Арктический регион является особой территорией экологического и социокультурного развития, поэтому он нуждается в основательной инфраструктурной, институциональной и культурной модернизации, а в целом в концептуально новой стратегии культурной политики.

Монография раскрывает истоки осмысления российской Арктики как культурной реальности в трудах отечественных и зарубежных исследователей, научных проектах ученых Арктического государственного института культуры и искусств. Арктика примечательна тем, что умело совершенствует механизмы адаптации к экстремальным условиям, сохраняет плюралингвизм, свой неповторимый уклад жизни, основанный на бережном отношении к природе, создает неповторимую культуру, отличающуюся мощным духом коллективизма крепко сплоченной общины.

В издании подробно освещается специфика арктической цивилизации, культурно-проектная и творческая деятельность народов Севера, включая инклюзивные культурные практики, а также роль субъектной составляющей, человеческого капитала в повышении благосостояния населения. Большое внимание уделено результатам социологических исследований по изучению культурных интересов населения Арктики, их удовлетворенности деятельностью учреждений культуры. Самостоятельный раздел связан с результатами мониторинга, посвященного оценке влияния информационно-коммуникативных технологий на социокультурную среду региона, анализу цифровизации и сайтостроения в регионе, оцифровке культурного наследия.

Монография выполнена в рамках государственного задания 35.10127.2017/HM. 